\title{
Synthesis of aryl pyrrolizidines from endocyclic enecarbamates. Novel applications of the Heck arylation of 3-pyrrolines using diazonium salts
}

\author{
Antonio C. B. Montes de Oca and Carlos Roque D. Correia* \\ Instituto de Química, Universidade Estadual de Campinas, P.O. Box 6154, Campinas, SP, \\ 13083-970, Brazil \\ E-mail: roque@iqm.unicamp.br
}

Dedicated to Professor Edmundo A. Rúveda on his $70^{\text {th }}$ birthday

(received 30 Aug 03; accepted 08 Oct 03; published on the web 12 Oct 03)

\begin{abstract}
The novel aryl platynecines $\mathbf{3 a} / \mathbf{3 b}$ were synthesized from endocyclic 4-aryl enecarbamates $\mathbf{8 a} / \mathbf{8 b}$ by a concise and practical route. The synthesis was based on an efficient preparation of 4-aryl enecarbamates $\mathbf{8 a} / \mathbf{8 b}$ from 3-pyrrolines by means of a Heck arylation using aryldiazonium tetrafluoroborates, followed by a highly stereoselective cycloaddition of the 4-aryl enecarbamates $\mathbf{8 a} / \mathbf{8 b}$ to 2-chloroethyl ketene to afford exclusively the 7-endo-(2-chloroethyl) cyclobutanones 12a/12b in good yields (67\% and 65\%). Baeyer-Villiger oxidation of the cyclobutanones $\mathbf{1 2 a} / \mathbf{1 2 b}$ occurred with high regioselectivity to furnish the aza-lactones $\mathbf{1 3 a} / \mathbf{1 3 b}$ in $96 \%$ and $90 \%$ yields. Reduction of lactones $\mathbf{1 3 a}$ and $\mathbf{1 3 b}$ with $\mathrm{LiAlH}_{4}$ gave the desired aryl platynecines 3a/3b. The total synthetic sequence involved 6 steps and provided the aryl platynecines $\mathbf{3 a} / \mathbf{3 b}$ in an overall yield of $41 \%$ and $38 \%$, respectively. These compounds are the first examples of necine bases bearing an aromatic substituent on the azabicyclo[3.3.0]octane framework and incorporate some of the key structural element of the pharmacologically active 1,3,4-trisubstituted pyrrolines which act as antagonists of the chemokine receptor CC5.
\end{abstract}

Keywords: Pyrrolizidines, endocyclic enecarbamates, Heck arylation, aryl pyrrolines, [2+2] cycloaddition, aryl platynecine

\section{Introduction}

Pyrrolizidine alkaloids (PAs) are a large family of natural products bearing an azabicyclo[3.3.0]octane as the main structural core. The necine bases are usually esterified to a diversity of mono- and dicarboxylic acids (Figure 1). ${ }^{1 \mathrm{a}, \mathrm{b}} \mathrm{PAs}$ possess quite intense and interesting biological and pharmacological activities and have been the subject of much attention among 
chemists and biologists. ${ }^{2 \mathrm{a}-\mathrm{e}}$ For example, the hepatotoxic retronecine $\mathbf{1}$ is the putative precursor for a number of insect pheromones, as well as the precursor of other necine bases such as hadinecine 2. ${ }^{3}$ Despite their biological and pharmacological activities very few modified pyrrolizidines and necine bases have been reported in the literature. ${ }^{2 a-e}$

We have previously reported on the synthesis of pyrrolizidines, necine bases and indolizidines, following an efficient synthetic methodology that involved the [2+2] cycloaddition of endocyclic enecarbamates to ketenes. ${ }^{4 a-c}$ Recently we decided to apply this methodology to the synthesis of hybrid necine bases and other pyrrolizidines in order to evaluate the influence of such modifications on the biological activities of these compounds. We were particularly interested in the introduction of aromatic groups to the azabicyclo[3.3.0]octane core, in view of recent reports on the outstanding pharmacological properties displayed by 1,3,4-trisubstituted pyrrolidines such as compounds $\mathbf{4}$ and $\mathbf{5}$, which exhibit subnanomolar activity against HIV infection. ${ }^{5}$ These compounds act as potent antagonists by selectively binding to the chemokine receptor CC5, a co-receptor for HIV infection. We envisioned the aryl pyrrolizidines as hybrid analogues of the 1,3,4-trisubstituted pyrrolidines $\mathbf{4}$ and $\mathbf{5}$ (Figure 1). Furthermore, to the best of our knowledge arylated pyrrolizidines are unreported compounds and therefore their pharmacological properties could be interesting in establishing some structure-activity relationship between them and the recently reported 1,3,4-trisubstituted pyrrolidines.

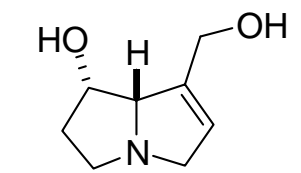

1

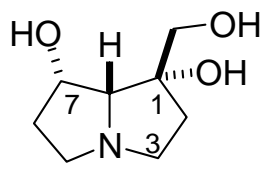

2

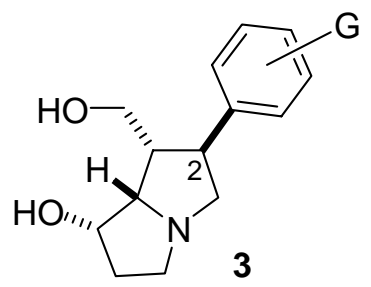

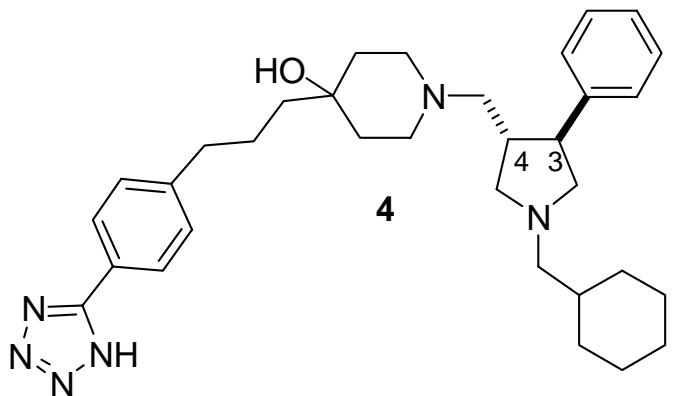

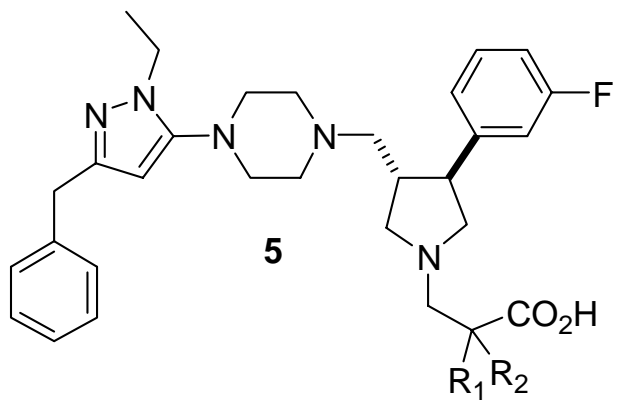

Figure 1. Examples of 1,3,4-trisubstituted pyrrolidines and some aryl pyrrolizidine analogues. 


\section{The synthetic methodology}

In addition to the specific interests mentioned above we wanted to develop a general synthetic route that could be applicable to the synthesis of new necine bases and pyrrolizidine alkaloids. The presence of electron rich aromatic ring on the structure of the necine base would serve not only as an element of structural diversity but also as a key functionality which would allow the introduction of groups such as carboxylic acids, esters, amides, and hydroxymethyl groups to the basic framework of the necine bases (see retrosynthetic analysis below). ${ }^{6}$

Our first approach to meet such objectives was based on two key methodologies already explored in our laboratory: (1) the [2+2] cycloaddition of enecarbamates to alkylketenes, ${ }^{4}$ and (2) the efficient preparation of 4-aryl enecarbamates from the Heck arylation of 3-pyrrolines. ${ }^{7}$ The availability of several 4-aryl endocyclic enecarbamates by this methodology was a motivation for the construction of the new aryl pyrrolizidines in our laboratory.

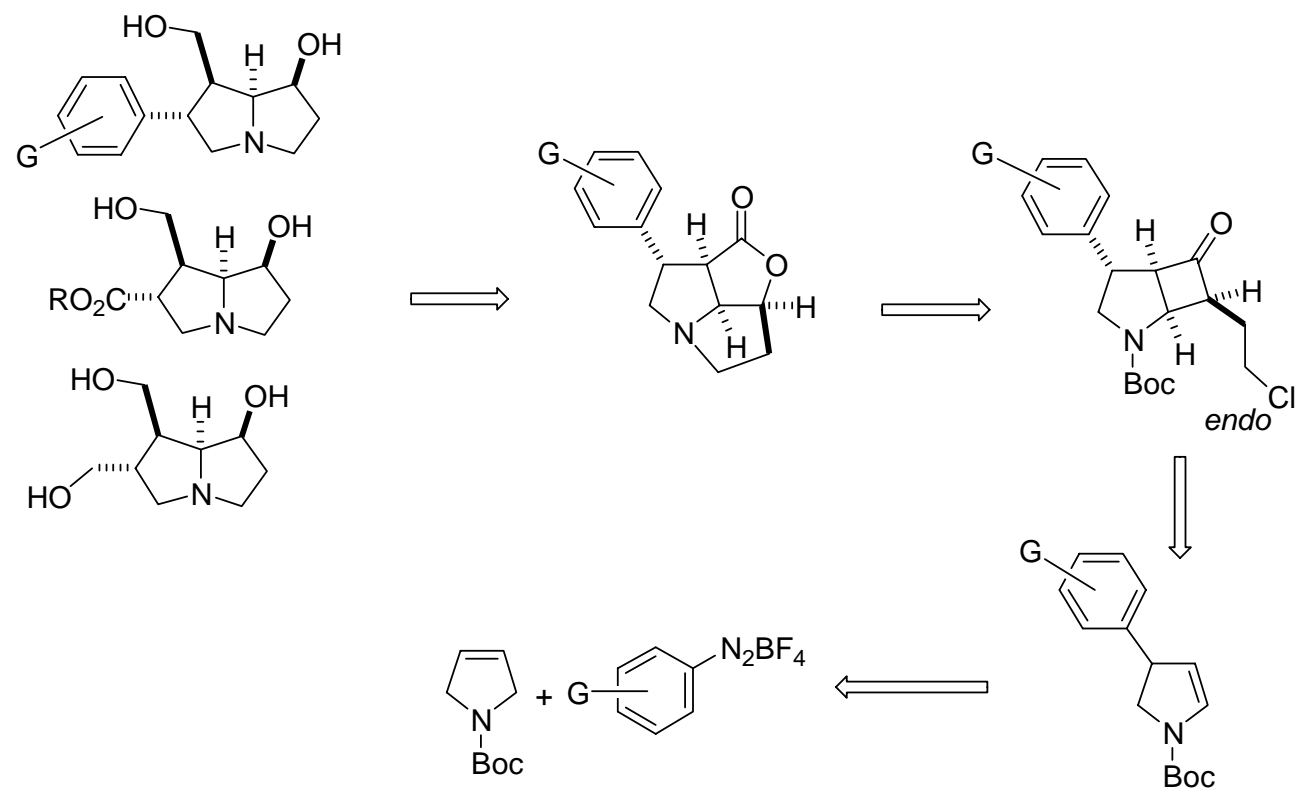

Figure 2. Retrosynthetic analysis for the synthesis of the new aryl pyrrolizidines.

\section{Results and Discussion}

The first step in our synthetic sequence was the synthesis of the 4-aryl enecarbamates. To include a significant range of electronic properties, we decided to prepare enecarbamates bearing $p$ chloro- and $o$-methoxyphenyl rings, and a quinonoid substituent. All three enecarbamates were obtained in good overall yields by the Heck arylation of 3-pyrroline $\mathbf{6}$ using the corresponding aryldiazonium tetrafluoroborate salts. The Heck arylation of olefins employing diazonium salts is an efficient and practical reaction, which does not require phosphine ligand (ligand-free 
conditions), inert atmosphere, anhydrous conditions, and is carried out within short reaction times. ${ }^{7}$

The 4-aryl enecarbamates $\mathbf{8 a} / \mathbf{8 b}$ bearing a $p$-chloro- and a $\boldsymbol{o}$-methoxyphenyl group were prepared in good overall yields from pyrroline $\mathbf{6}$ as described in Scheme 1. The use of $\mathrm{H}_{2} \mathrm{O} / \mathrm{CH}_{3} \mathrm{CN}$ as solvent was critical for solubilization of the diazonium salts 7 . As the reaction conditions do not require the presence of base, such as sodium acetate, the medium was allowed to become acidic as reaction progresses which resulted in the hydration of the 4-aryl enecarbamate intermediate to generate the corresponding $\mathrm{N}, \mathrm{O}$-hemiacetal (lactamol). This hydration step proved valuable as attempts to isolate the intervening enecarbamate at this stage proved fruitless or led to very low yields of the isolated enecarbamates $\mathbf{8 a} / \mathbf{8 b}$. On the other hand, the crude lactamols $\mathbf{9 a / 9 b}$ (mixture of cis and trans diastereomers) could be easily converted into the corresponding enecarbamates $\mathbf{8 a} / \mathbf{8 b}$ following a protocol previously described by us $(2,6-$ or 2,4-lutidine, trifluoroacetic anhydride) as exemplified below. ${ }^{8 .}$

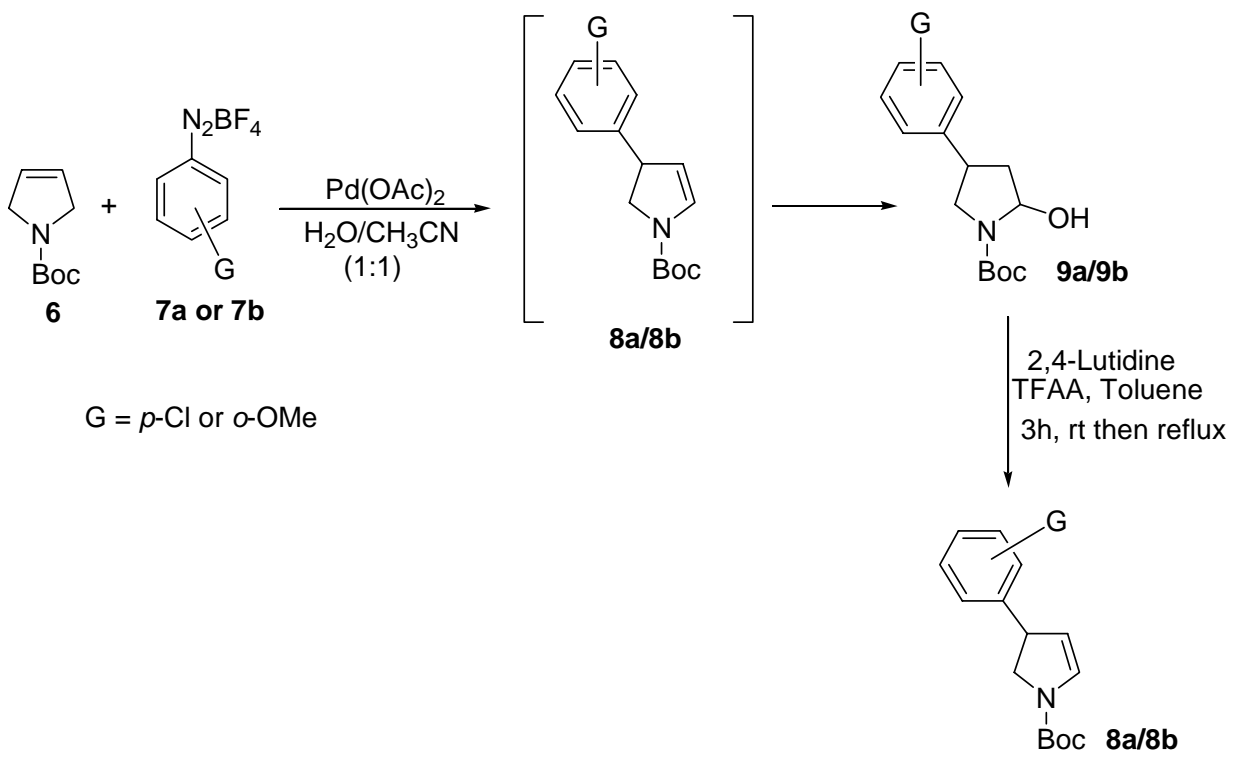

Scheme 1. Synthesis of the aryl endocyclic enecarbamates 8a/8b by the Heck methodology.

Illustration of the power of this methodology was the preparation of the 4-(1anthraquinonyl)-2-pyrroline 11. The choice of the 1-anthraquinonyl substituent was based on the marked biological activity displayed by anthraquinones and on the steric requirements imposed on the Heck arylation of olefins using a peri-substituted aryldiazonium salts (Scheme 2). ${ }^{9}$ 

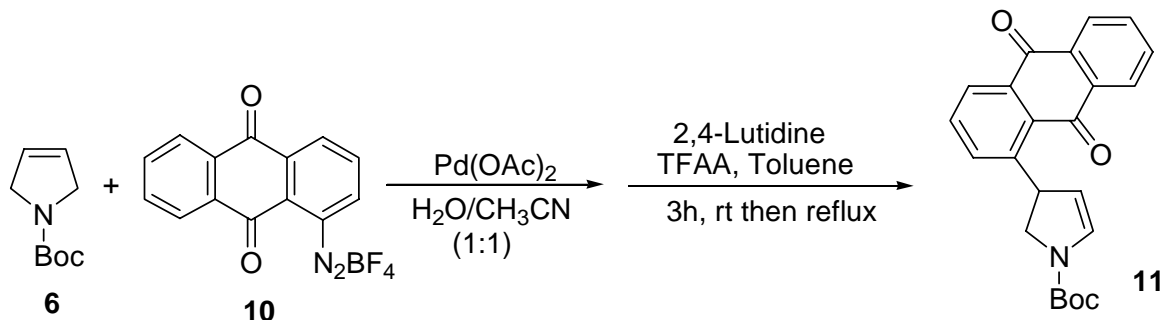

Scheme 2. Synthesis of enecarbamate 11 bearing an anthraquinonyl substituent.

The potential of the Heck arylation of olefins employing aryldiazonium salts is still little explored in synthesis and holds several advantages over the traditional Heck arylation protocols employing aryl triflates and aryl halides. ${ }^{10}$ Heck arylations with aryldiazonium salts are usually easier to carry out, cheaper, faster, and less demanding regarding reaction conditions.

The proposed mechanism for the Heck arylation of 3-pyrrolines (or to other similar olefins) most probably involves a cationic palladium (II) intermediate. The proposed catalytic cycle involving the 3-pyrroline is presented in Figure 3 below.

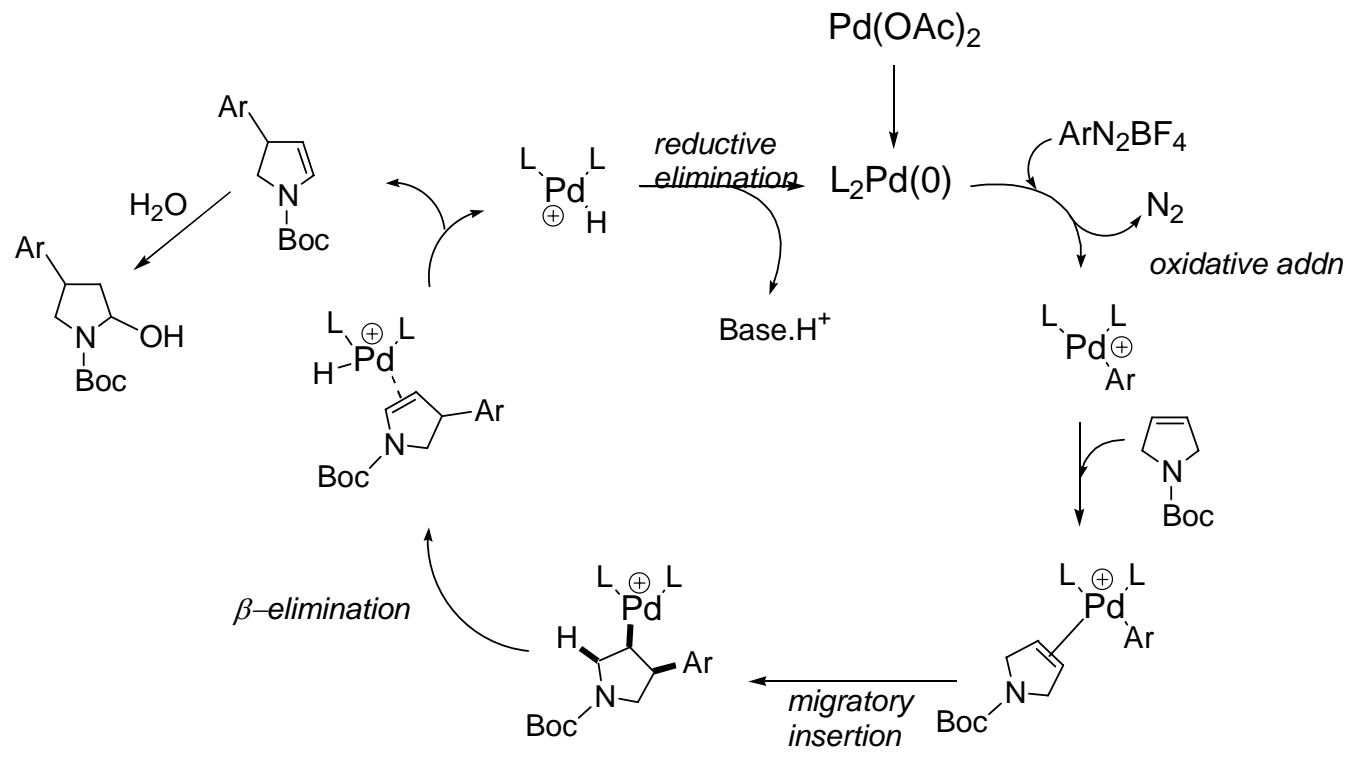

Figure 3. The proposed Heck catalytic cycle using aryldiazonium salts.

Heck arylation of 3-pyrrolines worked equally well with aryldiazonium salts bearing electron-withdrawing and electron-donating groups (halogens, nitro, esters, alkoxy and carboalkoxy groups). ${ }^{7}$

\section{The [2+2] cycloaddition step}

The [2+2] cycloaddition of enecarbamates to ketenes is another synthetic step well explored in our laboratory and it was planned to good stereocontrol due to the aryl substituent on the 
pyrrolidine ring. The expectation was of a high or exclusive stereoselectivity to the trans cycloadduct. From previous experiments with 5-substituted endocyclic enecarbamates we also learned that alkyl chains of the ketenes end up in a preferential endo configuration by virtue of the mechanism of [2+2]cycloaddition. Therefore, the endocyclic 4-aryl enecarbamates $\mathbf{8 a} / \mathbf{8 b}$ provided another opportunity to evaluate the stereoselectivity of the [2+2] cycloaddition.

According to our expectations, the [2+2]cycloaddition of the 4-aryl endocyclic enecarbamates $\mathbf{8 a} / \mathbf{8 b}$ to 2-chloroethyl ketene, generated in situ from 4-chlorobutanoyl chloride and triethylamine, afforded exclusively the endo-(2-chloroethyl) cyclobutanones 12a/12b in good isolated yields.

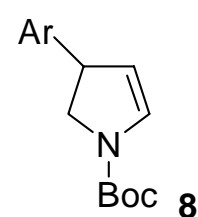

Ar:

$\mathbf{8 a}=p-\mathrm{ClC}_{6} \mathrm{H}_{4}$ $8 \mathbf{b}=o-\left(\mathrm{CH}_{3} \mathrm{O}\right) \mathrm{C}_{6} \mathrm{H}_{4}$
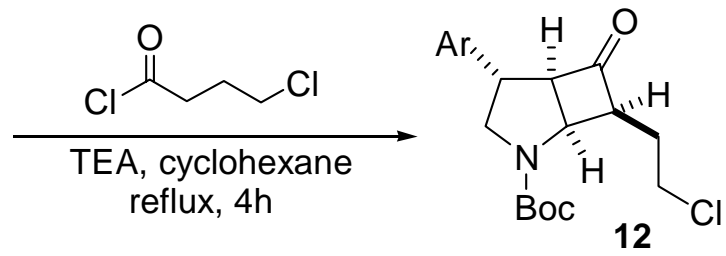

Ar:

$12 \mathrm{a}=p-\mathrm{ClC}_{6} \mathrm{H}_{4}(67 \%)$

$12 \mathbf{b}=0-\left(\mathrm{CH}_{3} \mathrm{O}\right) \mathrm{C}_{6} \mathrm{H}_{4}(65 \%)$

\section{Equation 1}

These results corroborate initial observations that the exo cycloadduct, obtained as minor product in some previous cycloadditions, is derived from the kinetic endo cycloadduct by epimerization promoted by the tetraethylammonium salt generated in the reaction. The degree of endo-stereoselectivity was significantly higher than the one obtained to cycloadditions of ketene to unsubstituted endocyclic enecarbamates. ${ }^{4 a}$

Despite some controversy concerning the actual mechanism of the [2+2] cycloaddition of ketenes to olefins, and in particular to endocyclic enecarbamates, we propose that the reaction follows the pathway presented in Figure 4. This mechanism for the [2+2] cycloaddition rationalizes the trans stereochemical outcome with respect to the aryl group and the endo positioning of the 2-chloroethyl side chain. 


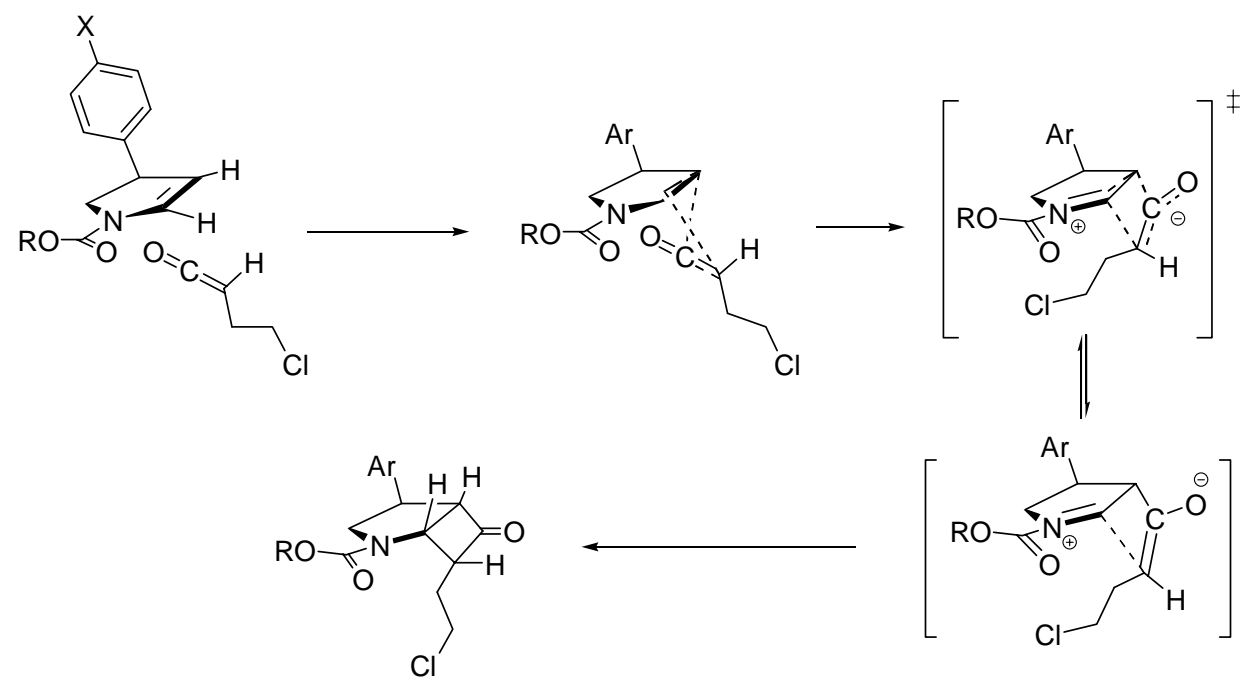

Figure 4. The proposed mechanism for the [2+2] cycloaddition.

Baeyer-Villiger ring expansion ${ }^{11}$ of the endo-7-(2-chloroethyl) cyclobutanones 12a/12b with meta-chloroperbenzoic acid ( $m$-CPBA) proceeded with remarkable high regioselectivity to provide the regioisomeric $\gamma$-butyrolactones 13a/13b depicted in Equation 2 as the only reaction products in high yields. The endo-alkyl cyclobutanones 12a/12b displayed an overwhelming preference for the migration of the C6-C7 bond over the C5-C6 bond during the Baeyer-Villiger reaction.

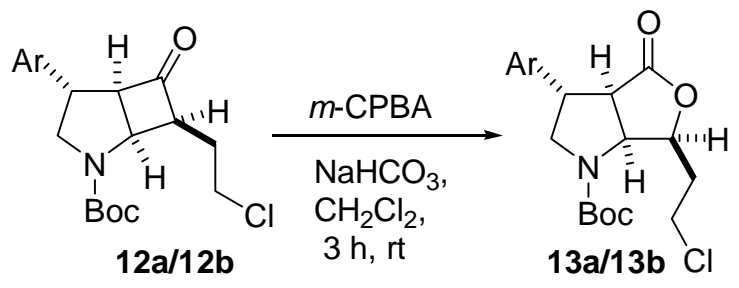

Ar: p-chlorophenyl; o-methoxyphenyl.

\section{Equation 2}

The reason for this high regioselectivity is not clear yet, but a possible rationale for this unusual regiochemical outcome might be the steric compression and stereoelectronic effects operating at the putative Criegee intermediate as depicted in Figure 5 for the endo and exo cycloadducts. The higher steric compression attributed to the endo 7-(2-chloroethyl) substituent and the hydroxyl group on the 2-azabicyclo[3.2.0]heptane core (Figure 5, a) makes the C6-C7 bond more prone to migration than the C5-C6 bond. On the other hand, positioning of the 7-(2chloroethyl) group in exo (Fig.5, b) seems to minimize steric compression among the 
substituents, making the migratory preference of the C6-C7 bond less pronounced, thus leading to the formation of regioisomeric lactones. ${ }^{4 a}$

7-endo:

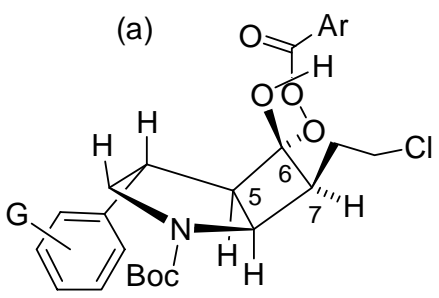

7-exo:

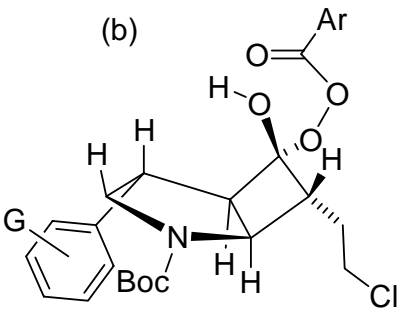

Figure 5. Steric compression in the putative Criegee intermediate.

With the key lactone intermediates $\mathbf{1 3 a} / \mathbf{1 3 b}$ secured we then proceeded to remove the Boc groups on nitrogen providing the driving force for the formation of the tricyclic aza-lactones 14a/14b. Indeed, removal of the Boc group with trifluoroacetic acid in dichloromethane, followed by neutralization of the resulting trifluoroacetate salt, resulted in the clean formation of the aryl aza-lactones 14a/14b in good yields (Scheme 3). The desired arylated platynecines were obtained by reduction of the corresponding lactones with lithium aluminum hydride at reflux for 2 hours, which provided the aryl platynecines $\mathbf{3 a} / \mathbf{3 b}$ as colorless oils in $85 \%$ and $84 \%$ yields, respectively.

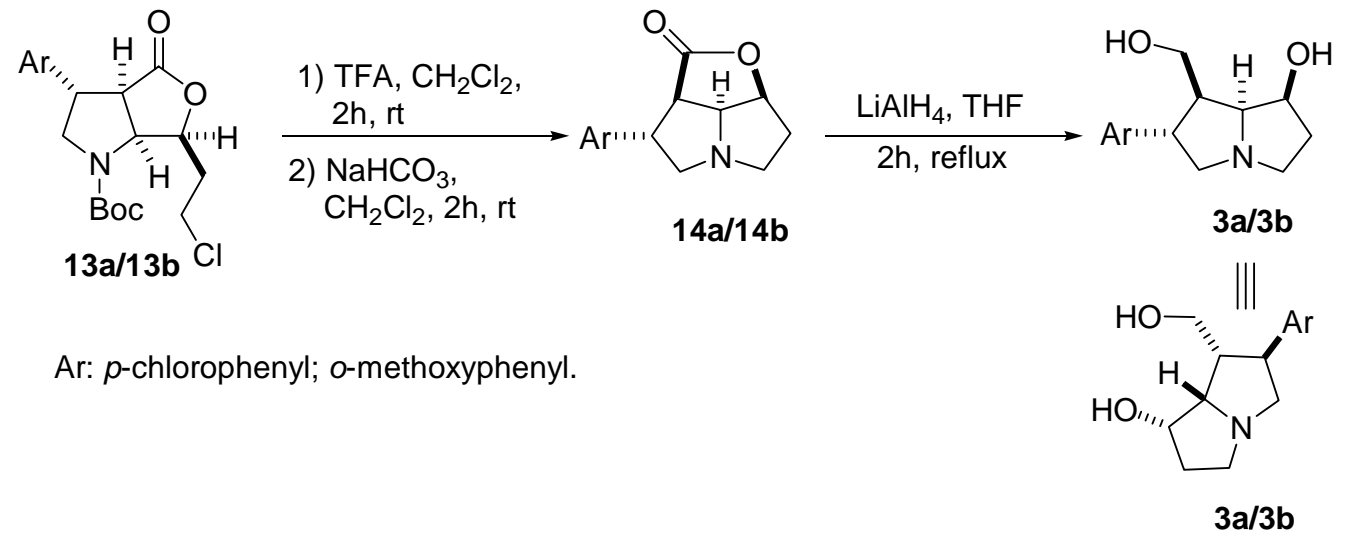

Scheme 3. The synthesis of aryl pyrrolizidines $3 \mathbf{a} / 3 \mathbf{b}$.

Further studies are ongoing to convert these novel necine bases into new noncoded dihydroxylated $\beta$-amino acid $\mathbf{1 5}$ and/or the trihydroxylated necine base $\mathbf{1 6 .}$ 


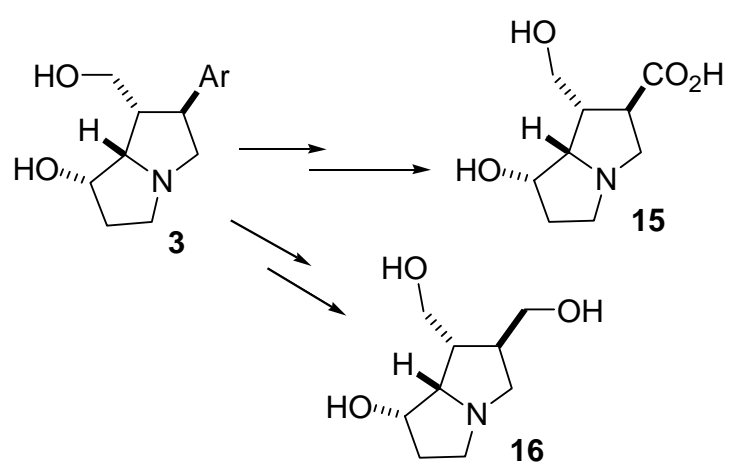

Figure 6. New potential pyrrolidines derived from the aryl platynecines.

\section{Conclusions}

The aryl platynecines $\mathbf{3 a / 3 b}$ bearing electron-withdrawing and electron-donating groups were synthesized from endocyclic 4-aryl enecarbamates $\mathbf{8 a} / \mathbf{8 b}$ in good overall yields (41\% and 38\%). The strategy was based on the efficient preparation of 4-aryl enecarbamates from 3-pyrrolines by means of a practical and reliable Heck arylation using aryldiazonium tetrafluoroborates following a highly stereoselective route previously developed in our laboratories. The novel 4aryl endocyclic enecarbamates $\mathbf{8 a} / \mathbf{8 b}$ underwent cycloaddition to 2-chloroethyl ketene to afford the corresponding 7-endo-(2-chloroethyl) cyclobutanones $\mathbf{1 2 a} / \mathbf{1 2 b}$ in good yields (67\% and $65 \%$ ) and with complete stereocontrol. Baeyer-Villiger oxidation of the cyclobutanones 12a/12b occurred with high regioselectivity to furnish the aza-lactones 13a/13b in $96 \%$ and $90 \%$ yields, respectively. Reduction of lactones $\mathbf{1 3 a}$ and $\mathbf{1 3 b}$ with lithium aluminum hydride gave the desired aryl platynecines $\mathbf{3 a / 3 \mathbf { b }}$ in good yields. The total synthetic sequence involved 6 steps and provided the aryl platynecines $\mathbf{3 a}$ and $\mathbf{3 b}$ in an overall yield of $41 \%$ and $38 \%$, respectively. These compounds are the first examples of necine bases bearing an aromatic substituent on the azabicyclo[3.3.0]octane framework and incorporate some of the key structural element of the pharmacologically active 1,3,4-trisubstituted pyrrolines which act as antagonists of the chemokine receptor CC5. The pharmacological properties of these novel compounds are under evaluation.

\section{Experimental Section}

General Procedures. Unless noted otherwise, all reactions were carried out under an atmosphere of dry nitrogen or argon, in oven-dried glassware. Methylene chloride, hexane, cyclohexane, and triethylamine were distilled from $\mathrm{CaH}_{2}$ prior to use. Tetrahydrofuran was distilled from sodium/benzophenone ketyl prior to use. Pyrrolidine and 4-chlorobutyryl chloride were also distilled prior to use. All other reagents were purchased from traditional commercial 
sources and used without further purification. Flash column chromatography was performed employing Merck silica gel 60 (230-400 mesh). Thin layer chromatography (TLC) was performed on Merck silica gel 60/F-254 aluminum-backed plates, and visualized by UV radiation and/or phosphomolybdic acid. Analytical high-performance liquid chromatography was carried out on a HP 1100 series chromatograph equipped with an UV detector. Capillary GLC analyses were performed on a Hewlett-Packard 6890 chromatograph equipped with fused-silica gel capillary column (30m x 0.32mm) wall coated with HP-5. Melting points were measured on a Thomas Hoover capillary melting point apparatus and are uncorrected. Nuclear magnetic resonance spectra $\left({ }^{1} \mathrm{H}\right.$ and $\left.{ }^{13} \mathrm{C} \mathrm{NMR}\right)$ were recorded as solutions in the indicated solvents on Varian Gemini 300 or Bruker AC-300P spectrometer. Chemical shifts are reported in parts per million ( $\delta$ units) relative to tetramethylsilane as internal standard $\left({ }^{1} \mathrm{H}\right.$ NMR). Infrared spectra were recorded on a Perkin-Elmer 399B, Perkin-Elmer 1600 (FTIR) or Nicolet Impact 410 spectrometers. Low resolution mass spectra were obtained on a Shimadzu QP5000 spectrometer, equipped with a HP-1 column $(0.20 \mathrm{~mm} \times 20 \mathrm{~m})$, and high resolution mass spectra on a VG Autospec Instrument. Elemental analyses were performed at the Chemistry Institute of the State University of Campinas.

Synthesis of the tert-butyl 2,5-dihydro-1H-pyrrole-1-carboxylate (6). To a $100 \mathrm{~mL}$ roundbottomed flask was added $1.48 \mathrm{~g}(15.2 \mathrm{mmol})$ of diallylamine dissolved in $30 \mathrm{~mL}$ of dry dichloromethane, followed by the addition of $2.1 \mathrm{~mL}$ of triethylamine $(30.4 \mathrm{mmol})$ and $3.49 \mathrm{~mL}$ $(15.2 \mathrm{mmol})$ of di-tert-butylcarbonate under argon atmosphere and the reaction mixture stirred at room temperature for $16 \mathrm{~h}$. When reaction was complete the medium was transferred to a separatory funnel and extracted with $5 \%$ citric acid solution and saturated $\mathrm{NaHCO}_{3}$, following by drying of the organic phase over anhydrous $\mathrm{Na}_{2} \mathrm{SO}_{4}$. The organic phase was then filtered and evaporated in vacuo to provide an oily residue that was used in the next step without purification. The crude oil dissolved in $60 \mathrm{~mL}$ of $\mathrm{CH}_{2} \mathrm{Cl}_{2}$ was placed in a dry $100 \mathrm{~mL}$ round-bottomed flask containing $0.193 \mathrm{~g}$ of the Grubbs catalyst $(1.5 \mathrm{~mol} \%)$ and the mixture stirred at room temperature for $13 \mathrm{~h}$. When TLC indicated complete consumption of the Boc-diallylamine the flask was opened to the atmosphere and stirred for an additional $3 \mathrm{~h}$. The solvent was then evaporated in vacuo and the residue flash chromatographed on silica gel (Hex/EtOAc: 95:5) to give $2.46 \mathrm{~g}$ of the $N$-Boc 3-pyrroline 6 (96\% over 2 steps).

I.R. (film, $\mathrm{cm}^{-1}$ ): 2977; 2861; 1702; 1624; 1478; 1404; 1367; 1121. ${ }^{1} \mathrm{HNMR}\left(300 \mathrm{MHz}, \mathrm{CDCl}_{3}\right.$, $\delta$, ppm): 1.46 (9H, s); 4.09 (4H, brs); 5.75 (2H, s). ${ }^{13} \mathrm{CNMR}\left(75 \mathrm{MHz}, \mathrm{CDCl}_{3}, \delta, \mathrm{ppm}\right): 28.9$ $\left(\mathrm{CH}_{3}\right) ; 35.8\left(2 \mathrm{CH}_{2}\right) ; 79.2(\mathrm{C}) ; 125.8(2 \mathrm{CH}) ; 154.5(\mathrm{C})$.

Synthesis of the tert-butyl 3-aryl-2,3-dihydro-1H-pyrrole-1-carboxylate (8). General procedure for the Heck arylation and conversion to the corresponding endocyclic enecarbamate: To a $100 \mathrm{~mL}$ round-bottomed flask charged with $1.0 \mathrm{~g}(5.92 \mathrm{mmol})$ of $N$-Boc-3-pyrroline 6 dissolved in $40 \mathrm{~mL}$ of water/acetonitrile (1:1) was added $3.9 \mathrm{mmol}$ of the aryldiazonium tetrafluoroborate 7 or 10 (olefin/aryldiazonium, 1.5:1) and $0.016 \mathrm{~g}$ (1.5 mol\%) of $\mathrm{Pd}(\mathrm{OAc})_{2}$. A 
rapid evolution of nitrogen is visible and when nitrogen bubbling has stopped it was added 50 $\mathrm{mL}$ of EtOAc to the reaction medium followed by extraction in a separatory funnel. The organic phase was separated, washed with saturated $\mathrm{NaHCO}_{3}$ solution and dried over anhydrous $\mathrm{Na}_{2} \mathrm{SO}_{4}$. After filtration the solvent was evaporated in vacuo and the crude lactamol $\mathbf{9}$ used in the next step without further purification.

To a $50 \mathrm{~mL}$ two-necked flask equipped with a reflux condenser was added the lactamol 9 (obtained by the Heck arylation described above), $10 \mathrm{~mL}$ of toluene and $2.29 \mathrm{~mL}(19,7 \mathrm{mmol}$ ) of 2,4-lutidine under nitrogen atmosphere at $0{ }^{\circ} \mathrm{C}$. The reaction was stirred at $0{ }^{\circ} \mathrm{C}$ for $15 \mathrm{~min}$ followed by the addition of $5.6 \mathrm{~mL}$ of $0.7 \mathrm{M}$ trifluoroacetic anhydride in toluene and stirred for 3 $\mathrm{h}$ at room temperature and then the reaction mixture refluxed for $1 \mathrm{~h}$ to complete elimination the conversion of the intermediate trifluoroacetate to the endocyclic enecarbamate $\mathbf{8}$. The reaction medium was cooled in ice water followed by the addition of $20 \mathrm{~mL}$ of saturated $\mathrm{Na}_{2} \mathrm{CO}_{3}$. The reaction mixture was transferred to a separatory funnel, the layers were separated and the aqueous layer was extracted twice with $5 \mathrm{~mL}$ of toluene. The combined organic layers were dried over anhydrous sodium sulfate, filtered and evaporated in vacuo to provide a residue which was flash chromatographed in silica gel (Hexane/EtOAc: 95:5) to furnish the enecarbamates 8 or 11 as oil (73-78\% over the 2 steps).

tert-Butyl 3-(4-chlorophenyl)-2,3-dihydro-1H-pyrrole-1-carboxylate (8a) (76\% yield). I.R. (film, $\mathrm{cm}^{-1}$ ): 3111; 2979; 2939; 1705; 1616; 1135; 1095; 827. ${ }^{1} \mathrm{H}-\mathrm{NMR} \quad\left(300 \mathrm{MHz}, \mathrm{CCl}_{4}\right)$ : mixture of rotamers, $\delta 1.46(9 \mathrm{H}, \mathrm{s}) ; 3.53(1 \mathrm{H}, \mathrm{m}) ; 4.08(2 \mathrm{H}, \mathrm{m}) ; 4.92-4.97(1 \mathrm{H}, \mathrm{m}) ;(6.54-6.74$ $(1 \mathrm{H}, \mathrm{d}) ; 7.10-7.22$ (4H, m). ${ }^{13} \mathrm{C}-\mathrm{NMR}\left(\mathrm{CCl}_{4}, 75 \mathrm{MHz}\right): \delta 28.3\left(3 \mathrm{CH}_{3}\right) ; 46.4(\mathrm{CH}) ; 53.5\left(\mathrm{CH}_{2}\right)$; 79.3 (C); 109.5 (CH); 128.2 (2 CH); 128.5 (2 CH); 130.7 (CH); 132.5 (C); 142.3 (C); 149.8 (C). tert-Butyl 3-(2-methoxyphenyl)-2,3-dihydro-1H-pyrrole-1-carboxylate (8b) (78\% yield). I.R. (film, cm ${ }^{-1}$ ): 3111; 2969; 2937; 1704; 1616; 1133; 1030; 888; 756. ${ }^{1} \mathrm{H}-\mathrm{NMR}\left(300 \mathrm{MHz}, \mathrm{CCl}_{4}\right)$ : mixture of rotamers, $\delta 1.43(9 \mathrm{H}, \mathrm{s}) ; 3.34(1 \mathrm{H}, \mathrm{m}) ; 3.80(3 \mathrm{H}, \mathrm{s}) ; 4.05-4.50(2 \mathrm{H}, \mathrm{m}) ; 5.00(1 \mathrm{H}, \mathrm{m})$; 6.54-6.74 (1H, d); 6.80-7.50 (4H, m). ${ }^{13} \mathrm{C}-\mathrm{NMR}\left(\mathrm{CCl}_{4}, 75 \mathrm{MHz}\right): \delta 28.2\left(3 \mathrm{CH}_{3}\right) ; 46.1(\mathrm{CH})$; $52.8\left(\mathrm{CH}_{2}\right) ; 55.6\left(\mathrm{CH}_{3}\right) ; 80.0(\mathrm{C}) ; 109.8(\mathrm{CH}) ; 110.2(\mathrm{CH}) ; 120.3(\mathrm{CH}) ; 120.5(\mathrm{C}) ; 126.1(\mathrm{CH}) ;$ $128.5(\mathrm{CH}) ; 130.7$ (CH); $142.3(\mathrm{C}) ; 149.8$ (C).

tert-Butyl 3-(9,10-dioxo-9,10-dihydro-1-anthracenyl)-2,3-dihydro-1H-pyrrole-1-carboxylate (11). Obtained as faint yellow oil (73\% yield over 2 steps). I.R. (film, $\mathrm{cm}^{-1}$ ): 3113; 2973; 2937; 2890; 1692; 1670; 1617; 1579; 1405; 1364; 1297; 1133; 1030; 710. ${ }^{1} \mathrm{H}-\mathrm{NMR}$ (300 MHz, $\left.\mathrm{CDCl}_{3}\right)$ : mixture of rotamers, $\delta 1.45(9 \mathrm{H}, \mathrm{s}) ; 3.50(1 \mathrm{H}, \mathrm{m}) ; 4.52(1 \mathrm{H}, \mathrm{s}) ; 5.35(1 \mathrm{H}, \mathrm{m}) ; 6.76-6.92$ $(1 \mathrm{H}, \mathrm{m}) ; 7.75(4 \mathrm{H}, \mathrm{m}) ; 8.30(3 \mathrm{H}, \mathrm{m}) .{ }^{13} \mathrm{C}-\mathrm{NMR}\left(75 \mathrm{MHz}, \mathrm{CCl}_{4}\right): \delta 28.3\left(3 \mathrm{CH}_{3}\right) ; 45.2(\mathrm{CH}) ; 53.7$ $\left(\mathrm{CH}_{2}\right) ; 80.2(\mathrm{C}) ; 109.3(\mathrm{CH}) ; 126.5(2 \mathrm{CH}) ; 127.0(\mathrm{CH}) ; 130.5(\mathrm{CH}) ; 131.4(\mathrm{C}) ; 131.8(\mathrm{C}) ; 132.4$ (C); 133.4 (CH); 133.9 (CH); 134.2 (C); 134.4 (CH); 134.5 (CH); 134.8 (C); 146.7 (C); 182.9 (2C).

Synthesis of the tert-butyl 7-(2-chloroethyl)-4-(aryl)-6-oxo-2-azabicyclo[3.2.0]heptane-2carboxylates (12). General procedure: A two-necked round-bottomed flask equipped with a reflux condenser was charged with the aryl enecarbamate $8(0.73 \mathrm{mmol}), 0.29 \mathrm{~mL}$ of triethylamine and $4 \mathrm{~mL}$ of dry cyclohexane and warmed to reflux. To this solution, under $\mathrm{N}_{2}$ 
atmosphere, was slowly added 4-chlorobutanoyl chloride $(0.22 \mathrm{~mL} ; 1.8 \mathrm{mmol})$ dissolved in $5 \mathrm{~mL}$ of cyclohexane over a period of $2 \mathrm{~h}$. The resulting yellowish suspension was left at reflux for an additional $2 \mathrm{~h}$, then it was cooled to room temperature and filtered. The precipitate was extracted with EtOAc-hexane [1:2], the combined organic phases washed with a $10 \% \mathrm{NaHCO}_{3}$ solution and dried over anhydrous $\mathrm{Na}_{2} \mathrm{SO}_{4}$. Evaporation of the solvents in vacuo provided an yellowish oil which by flash chromatography ( $\mathrm{Et}_{2} \mathrm{O} /$ hexane, 40:60) to give the corresponding azacyclobutanones 12 as homogeneous materials by TLC.

tert-Butyl 7-(2-chloroethyl)-4-(4-chlorophenyl)-6-oxo-2-azabicyclo[3.2.0]heptane-2-carboxylate (endo-alkyl group) (12a). Obtained in 67\% yield. I.R. (film, $\mathrm{cm}^{-1}$ ): 2976; 2831; 2870; 1780; 1695; 1491; 1394; 1159; 833. ${ }^{1} \mathrm{H}-\mathrm{NMR}\left(300 \mathrm{MHz}, \mathrm{CCl}_{4}\right.$ ) ) mixture of rotamers, $\delta 1.47$ (9H, s); 1.96 (2H, m); 3.67 (7H, m); 4.79-4.93 (1H, t, $J=7.3 \mathrm{~Hz}) ; 7.03(2 \mathrm{H}, \mathrm{d}, J=8.4 \mathrm{~Hz}) ; 7.26$ (2H, d, $J$ $=8.4 \mathrm{~Hz}) .{ }^{13} \mathrm{C}-\mathrm{NMR}\left(75 \mathrm{MHz}, \mathrm{CCl}_{4}\right)$ : mixture of rotamers, $\delta 28.4\left(3 \mathrm{CH}_{3}\right) ; 29.2\left(\mathrm{CH}_{2}\right) ; 32.0$ $\left(\mathrm{CH}_{2}\right) ; 39.1(\mathrm{CH}) ; 41.9\left(\mathrm{CH}_{2}\right) ; 43.1(\mathrm{CH}) ; 43.5(\mathrm{CH}) ; 54.6(\mathrm{CH}) ; 80.9(\mathrm{C}) ; 127.0(2 \mathrm{CH}) ; 129.0$ (2CH), 141.0 (C); 143.0 (C); 170.0 (C); 205.5 (C). HRMS: calculated for $\mathrm{C}_{19} \mathrm{H}_{23} \mathrm{Cl}_{2} \mathrm{NO}_{3}$ 384.10550, obtained: $384.10773\left(\mathrm{M}^{+}\right)$.

tert-Butyl 7-(2-chloroethyl)-4-(2-methoxyphenyl)-6-oxo-2-azabicyclo[3.2.0]heptane-2-carboxylate (endo-alkyl group) (12b). Obtained in 65\% yield. I.R. (film, $\mathrm{cm}^{-1}$ ): 2969; 2935; 2870; 1782; 1694; 1499; 1391; 1167; 1025; 751. ${ }^{1} \mathrm{H}-\mathrm{NMR}$ (300 $\mathrm{MHz}, \mathrm{CDCl}_{3}$ ): mixture of rotamers, $\delta 1.49$ $(9 \mathrm{H}, \mathrm{s}) ; 1.90-2.10$ (2H, m); 3.57-4.05 (10H, m); 4.86-4.93 (1H, t); 6.83-7.23 (4H, m). ${ }^{13} \mathrm{C}-\mathrm{NMR}$ (75 MHz, $\left.\mathrm{CDCl}_{3}\right)$ : mixture of rotamers, $\delta: 27.5\left(\mathrm{CH}_{2}\right) ; 28.3\left(3 \mathrm{CH}_{3}\right) ; 37.6\left(\mathrm{CH}_{2}\right) ; 42.6(\mathrm{CH}) ; 52.7$ $\left(\mathrm{CH}_{2}\right)$; $53.3(\mathrm{CH}) ; 55.2\left(\mathrm{CH}_{3}\right) ; 60.6(\mathrm{CH}) ; 68.8(\mathrm{CH}) ; 80.4(\mathrm{C}) ; 110.2(\mathrm{CH}) ; 120.3(\mathrm{CH})$; 120.5(C); 126.1 (CH); 130.5 (CH); 153.8 (C); 156.2 (C); 210.9 (C).

Synthesis of the tert-butyl 6-(2-chloroethyl)-3-aryl-4-oxohexahydro-1H-furo[3,4-b]pyrrole1-carboxylate (endo-alkyl) (13). General procedure: To a $25 \mathrm{~mL}$ round-bottomed flask containing $0.27 \mathrm{mmol}$ of the endo-alkyl cyclobutanone 12 and $0.045 \mathrm{~g}(0.54 \mathrm{mmol})$ of $\mathrm{NaHCO}_{3}$ in $10 \mathrm{~mL}$ of $\mathrm{CH}_{2} \mathrm{Cl}_{2}$, at room temperature, was slowly added a solution of $m$-chloro perbenzoic acid (0.133 g, $0.77 \mathrm{mmol}$, dissolved in $8 \mathrm{~mL}$ of $\mathrm{CH}_{2} \mathrm{Cl}_{2}$ ). The reaction mixture was left stirring for $4 \mathrm{~h}$ when complete consumption of the starting material was observed by TLC. The mixture was then treated with saturated sodium sulfite solution ( $2 \times 15 \mathrm{~mL})$ and saturated sodium bicarbonate $(15 \mathrm{~mL})$. Next, the organic layer was separated, dried over $\mathrm{Na}_{2} \mathrm{SO}_{4}$, and filtered. The solvent was then evaporated in vacuo to give a crude oil, which was flash chromatographed $\left(\mathrm{SiO}_{2}, 40 \% \mathrm{Et}_{2} \mathrm{O}\right.$ in hexane) to furnish the corresponding lactones 13.

tert-Butyl 6-(2-chloroethyl)-3-(4-chlorophenyl)-4-oxohexahydro-1H-furo[3,4-b]pyrrole-1carboxylate (endo-alkyl group) (13a). Obtained in 96\% yield. Mp.: 108-109 ${ }^{\circ}$ C. I.R. (film, $\mathrm{cm}^{-1}$ ): 2974; 2930; 1772; 1694; 1489; 1391; 1157; 1015; 830. ${ }^{1} \mathrm{H}-\mathrm{NMR}$ (300 MHz, DMSO-d $d_{6}$ ) mixture of rotamers, $\delta: 1.42(9 \mathrm{H}, \mathrm{s}) ; 2.16(2 \mathrm{H}, \mathrm{m})$; 3.39-3.95 $(6 \mathrm{H}, \mathrm{m}) ; 4.85(2 \mathrm{H}, \mathrm{s}) ; 7.18-7.35(4 \mathrm{H}, \mathrm{m}) .{ }^{13} \mathrm{C}-$ NMR (75 MHz, CCl 4$)$ mixture of rotamers, $\delta$ : $28.1\left(3 \mathrm{CH}_{3}\right) ; 33.0\left(\mathrm{CH}_{2}\right) ; 40.6\left(2 \mathrm{CH}_{2}\right) ; 45.4(\mathrm{CH})$; $52.2(\mathrm{CH}) ; 52.6(\mathrm{CH}) ; 79.2(\mathrm{CH}) ; 80.2(\mathrm{C}) ; 127.2(2 \mathrm{CH}) ; 129.0(2 \mathrm{CH}) ; 133.2(\mathrm{C}) ; 136.0(\mathrm{C})$; 
168.0 (C); 173.6 (C). HRMS: calculated for $\mathrm{C}_{19} \mathrm{H}_{23} \mathrm{Cl}_{2} \mathrm{NO}_{4}$ : 399.10041, obtained: 399.09908 $\left(\mathrm{M}^{+}\right)$.

tert-Butyl 6-(2-chloroethyl)-3-(2-methoxyphenyl)-4-oxohexahydro-1H-furo[3,4-b]pyrrole-1carboxylate (endo-alkyl group) (13b). Obtained in 90\% yield. I.R. (film, $\mathrm{cm}^{-1}$ ): 2974; 2930; 1777; 1689; 1494; 1391; 1162; 1035; 756. ${ }^{1} \mathrm{H}-\mathrm{NMR}\left(300 \mathrm{MHz}\right.$, DMSO-d $\left.d_{6}\right)$ mixture of rotamers, $\delta: 1.47$ (9H, s); 2.16-2.40 (2H, m); 3.39-3.95 (9H, m); 4.65-4.80 (2H, s); 6.90-7.50 (4H, m). MS (Quadrupole Ion-trap): $396.3\left(\mathrm{M}^{+}+\mathrm{H}\right)$; 340.2; 296.2; 278.2; 250.2; 218.3; 174.3 150.2.

( \pm )-(1R,6R,7S)-6-(Aryl)-7-(hydroxymethyl)hexahydro-1H-pyrrolizin-1-ol (3). General procedure: To a solution of the bicyclic lactone $13(0.055 \mathrm{mmol})$ in $1.5 \mathrm{~mL}$ of $\mathrm{CH}_{2} \mathrm{Cl}_{2}$ was slowly added $0.05 \mathrm{~mL}$ of trifluoroacetic acid and the solution stirred at room temperature for $2 \mathrm{~h}$ when complete consumption of the starting lactone was observed by TLC. Solid $\mathrm{NaHCO}_{3}$ was then added to the reaction mixture and stirred for an additional $2 \mathrm{~h}$. Evaporation of the solvent in vacuo provided a viscous oil. This oil was dissolved in $1 \mathrm{~mL}$ of THF and to this solution, at room temperature, was slowly added a solution of $\mathrm{LiAlH}_{4}\left(0.1 \mathrm{~mL}\right.$ of a $1 \mathrm{M}$ in $\mathrm{Et}_{2} \mathrm{O}$ dissolved in 1.5 $\mathrm{mL}$ of dry THF). After addition of the $\mathrm{LiAlH}_{4}$ solution the reaction mixture was refluxed for $2 \mathrm{~h}$. To the resulting solution was then added $0.1 \mathrm{~mL}$ of $\mathrm{H}_{2} \mathrm{O}, 0.1 \mathrm{~mL}$ of $\mathrm{NaOH} 15 \%$ and $0.3 \mathrm{~mL}$ of $\mathrm{H}_{2} \mathrm{O}$ to form a white precipitate. The mixture was filtered over Celite, and the solvent removed in vacuo to give a residue which was dissolved in $\mathrm{CHCl}_{3}$ and dried over anhydrous $\mathrm{Na}_{2} \mathrm{SO}_{4}$. After filtration, the solvent was evaporated in vacuo and the resulting oil was flash chromatographed $\left(\mathrm{SiO}_{2}, \mathrm{CHCl}_{3} / \mathrm{MeOH} / \mathrm{NH}_{4} \mathrm{OH}, 2: 7: 1\right)$ to provide the corresponding aryl pyrrolizidine systems as colorless oils.

( \pm )-(1R,6R,7S)-6-(4-Chlorophenyl)-7-(hydroxymethyl)hexahydro-1H-pyrrolizin-1-ol (3a). Obtained in 85\% yield over 2 steps. I.R. (film, $\mathrm{cm}^{-1}$ ): 3437; 2921; 2850; 1630; 1462; $1104 .{ }^{1} \mathrm{H}-$ NMR (500 MHz, DMSO- $\left.d_{6}\right) \delta: 1.72(2 \mathrm{H}, \mathrm{m}, J=8.2 \mathrm{~Hz}, J=7.9 \mathrm{~Hz}) ; 2.41(1 \mathrm{H}, \mathrm{m}, J=7.9 \mathrm{~Hz}, J$ $=3.9 \mathrm{~Hz}, J=7.6 \mathrm{~Hz}) ; 2.78(1 \mathrm{H}, \mathrm{q}, J=7.9 \mathrm{~Hz}) ; 2.95(2 \mathrm{H}, \mathrm{m}, J=8.8 \mathrm{~Hz}) ; 3.10(1 \mathrm{H}, \mathrm{t}, J=8.2$ $\mathrm{Hz}) ; 3.30(2 \mathrm{H}, \mathrm{m}) ; 3.49(1 \mathrm{H}, \mathrm{dd}, J=3.9 \mathrm{~Hz}, J=10.3 \mathrm{~Hz}) ; 3.701 \mathrm{H}, \mathrm{t}, J=7.9 \mathrm{~Hz}) ; 4.15(1 \mathrm{H}, \mathrm{t}, J$ $=8.5 \mathrm{~Hz}) ; 4.81(2 \mathrm{H}, \mathrm{s}) ; 7.21(2 \mathrm{H}, \mathrm{d}) ; 7.32(2 \mathrm{H}, \mathrm{d}) .{ }^{13} \mathrm{C}-\mathrm{NMR}\left(75 \mathrm{MHz}, \mathrm{DMSO}-d_{6}\right) \delta: 35.8$ $\left(\mathrm{CH}_{2}\right) ; 44.9(\mathrm{CH}) ; 50.4(\mathrm{CH}) ; 54.0\left(\mathrm{CH}_{2}\right) ; 59.3\left(\mathrm{CH}_{2}\right) ; 64.4\left(\mathrm{CH}_{2}\right) ; 71.1(\mathrm{CH}) ; 72.0(\mathrm{CH}) ; 128.2$ $(\mathrm{CH}) ; 129.4(\mathrm{CH}) ; 130.6(\mathrm{C}) ; 142.0$ (C). HRMS: calculated for $\mathrm{C}_{14} \mathrm{H}_{18} \mathrm{ClNO}_{2}$ : 267.10260, obtained $267.10265\left(\mathrm{M}^{+}\right)$.

( \pm )-(1R,6R,7S)-7-(Hydroxymethyl)-6-(2-methoxyphenyl)hexahydro-1H-pyrrolizin-1-ol (3b). Obtained in 85\% yield over 2 steps. I.R. (film, $\left.\mathrm{cm}^{-1}\right): 3432 ; 2921 ; 2869 ; 1632 ; 1462 ; 1107 ; 757$. ${ }^{1} \mathrm{H}-\mathrm{NMR}\left(500 \mathrm{MHz}\right.$, DMSO- $d_{6}$, ) $\delta: 1.89(3 \mathrm{H}, \mathrm{m}) ; 2.71(1 \mathrm{H}, \mathrm{m}) ; 3.15(2 \mathrm{H}, \mathrm{m}) ; 3.35-3.50(2 \mathrm{H}$, $\mathrm{m})$; 3.76-3.83 (6H, m); 4.41 (1H, m); $4.83(1 \mathrm{H}, \mathrm{s}) ; 5.33(1 \mathrm{H}, \mathrm{s}) ; 6.94(2 \mathrm{H}, \mathrm{m}) ; 7.23(2 \mathrm{H}, \mathrm{m}){ }^{13} \mathrm{C}-$ NMR (75 MHz, DMSO-d $\left.d_{6}\right) \delta$ : $35.6\left(\mathrm{CH}_{2}\right) ; 38.2(\mathrm{CH}) ; 47.8(\mathrm{CH}) ; 54.0\left(\mathrm{CH}_{2}\right) ; 55.3\left(\mathrm{CH}_{3}\right) ; 58.3$ $\left(\mathrm{CH}_{2}\right) ; 61.14\left(\mathrm{CH}_{2}\right) ; 70.3(\mathrm{CH}) ; 72.3(\mathrm{CH}) ; 104.2(\mathrm{CH}) ; 110.9(\mathrm{CH}) ; 120.5(\mathrm{C}) ; 127.2(\mathrm{CH})$; 127.7 (CH); 157.3 (C). MS (Quadrupole Ion-trap): $264.3\left(\mathrm{M}^{+}+\mathrm{H}\right)$; 246.3; 228.3; 212.3; 184.3; 174.3; 121.2; 91.1; 86.3. 


\section{Acknowledgments}

The authors would like to thank the State of São Paulo Research Support Agency (FAPESP) for financial support and the Brazilian National Research Council (CNPq) and CAPES for fellowships.

\section{References}

1. (a) Liddel, J. R. Nat. Prod. Rep. 2000, 17, 455. (b) Robins, D. Chem. Soc. Rev. 1989, 18, 375.

2. (a) Mattoc, A. R. Chemistry and Toxicology of Pyrrolizidine Alkaloids, Academic Press: London, 1986.

(b) Cooper, R. A.; Huxtable, R. Toxicon 1996, 34, 604. (c) Couet, C. E.; Hopley, J.; Hanley, A. B. Toxicon. 1996, 34, 1058. (d) Ober, D.; Hartmann, T. J. Bio. Chem. 1999, 274, 32040. (e) Gordon, G. J.; Coleman, W. B.; Grisham, J. W. Experimental and Molecular Pathology. 2000, 69, 17.

3. Hanselmann R.; Benn, M. Tetrahedron Lett. 1993, 34, 3511.

4. (a) Faria, A. R.; Salvador, E. L.; Correia, C. R. D. J. Org. Chem. 2002, 67, 3651. (b) Faria, A. R.; Matos, C. R.; Correia, C. R. D. Tetrahedron Lett. 1993, 34, 27. (c) Faria, A. R.; Carvalho, E. S.; Correia, C. R. D. Tetrahedron Lett. 1995, 36, 5109.

5. (a) Willoughby, C. A.; Rosauer, K. G.; Hale, J. J.; Budhu, R. J.; Mills, S. G.; Chapman, K. T.; MacCoss, M.; Malkowitz, L.; Springer, M. S.; Gould, S. L.; DeMartino, J. Á.; Siciliano, S. J.; Cascieri, M. A.; Carella, A.; Carver, G.; Holmes, K.; Schleif, W. A.; Danzeisen, R.; Hazuda, D.; Kessler, J.; Lineberger, J.; Miller, M.; Emini, E. A. Bioorg. Med. Chem. Lett. 2003, 13, 427. (b) Lynch, C. L.; Hale, J. J.; Budhu, R. J.; Gentry, A. L.; Mills, S. G.; Chapman, K. T.; MacCoss, M.; Malkowitz, L.; Springer, M. S.; Gould, S. L.; DeMartino, J. Á.; Siciliano, S. J.; Cascieri, M. A.; Carella, A.; Carver, G.; Holmes, K.; Schleif, W. A.; Danzeisen, R.; Hazuda, D.; Kessler, J.; Lineberger, J.; Miller, M.; Emini, E. A. Bioorg. Med. Chem. Lett. 2002, 12, 3001. (c) Hale, J. J.; Budhu, R. J.; Mills, S. G.; MacCoss, M.; Gould, S. L.; DeMartino, J. A.; Springer, M. S.; Siciliano, S. J.; Malkowitz, L.; Schleif, W. A.; Hazuda, D.; Miller, M.; Kessler, J.; Danzeisen, R.; Holmes, K.; Lineberger, J.; Carella, A.; Carver, G.; Emini, E. A. Bioorg. Med. Chem. Lett. 2002, 12, 2997. (d) Lynch, C. L.; Hale, J. J.; Budhu, R. J.; Gentry, A. L.; Finke, P. E.; Caldwell, C. G.; Mills, S. G ; MacCoss, M.; Shen, D. M.; Chapman, K. T.; Malkowitz, L.; Springer, M. S.; Gould, S. L.; DeMartino, J. Á.; Siciliano, S. J.; Cascieri, M. A.; Carella, A.; Carver, G.; Holmes, K.; Schleif, W. A.; Danzeisen, R.; Hazuda, D.; Kessler, J.; Lineberger, J.; Miller, M.; Emini, E. Org. Lett. 2003, 5, 2473.

6. Garcia, A. L. L.; Correia, C. R.D. Tetrahedron Lett. 2003, 44, 1553.

7. Carpes, M. J. S.; Correia, C. R. D. Synlett 2000, 7, 1037.

8. Oliveira, D. F.; Miranda, P. C. M. L.; Correia, C. R. D. J. Org. Chem. 1999, 64, 6646.

9. Roe, A. Org. React. 1949, 5, 193.

10. (a) Cabri, W.; Candiani, I. Acc. Chem. Res. 1995, 28, 2. (b) Hallberg, A.; Clas, S.; Larbed, M.; Nyqvist, C. J. Org. Chem. 1996, 61, 4756.

11. Krow, G. R. In Comprehensive Organic Synthesis; Ley, S. V. Ed.; Pergamom Press: Oxford, 1991; Vol. 7, p 671. 